Gadjah Mada International Journal of Business

May-August 2007, Vol. 9, No. 2, pp. 137-156

\title{
RE-EXAMINING THE FINANCE-GROWTH NEXUS Empirical Evidence from Indonesia
}

\author{
M. Shabri Abd. Majid
}

This paper empirically examines the short-and long-run relationships between financial development and economic growth during the post-1997 financial crisis in Indonesia by employing a battery of times-series techniques, such as Autoregressive Distributed Lag (ARDL) model, vector error correction model (VECM), variance decompositions (VDCs), and impulse-response functions (IRFs). Based on the ARDL (2, 0, 1, 2) model, the study finds that there exists a long-run equilibrium between economic growth and financial depth, share of investment, and inflation. In the long run, inflation is found to be the only variable which significantly (negatively) affects economic growth, implying a crucial role of maintaining a low rate of inflation in promoting the economic growth in the country. As for the dynamic causalities among the variables, the study finds the bidirectional causation between economic growth and investment, while the unidirectional causation is only found running from financial depth to investment. The finding of independence between economic growth and financial development supports the view of "the independent hypothesis" of Lucas (1988). Finally, based on VDCs and IRFs, the study documents that the variations in the economic growth respond more to shocks in the price stability (inflation), followed by investment and financial development. Our findings indicate that if policy makers want to promote growth, attention should be focused on long-run policies, i.e., maintaining the low rate of inflation.

Keywords: ARDL; financial development; growth; impulse response function; Indonesia; multivariate causality

JEL Classification: C32, O16. 
adopting different methods, sets of data, and sample may lead to inconsistent findings. This study is, therefore, aimed at empirically re-examining short- and long-run relationships between financial development and economic growth in the Indonesian economy during the post-1997 financial turmoil by adopting the latest technique, which is autoregressive distributed lag (ARDL) bound testing approach to examine the cointegration. It also attempts to investigate the finance-growth nexus using multivariate causality tests within a vector error correction model (VECM). Finally, the paper also seeks to explore the relative strength of the variables in affecting economic growth using the variance decompositions (VDCs) and the impulse response function (IRFs) based on the structural vector autoregression (VAR) framework.

The rest of the paper is organized as follows. Section 2 discusses the theoretical issues on the relationship between financial development and economic growth. The empirical framework and data utilized in this study are delineated in Section 3. The empirical results and discussion on the findings are presented in Section 4. Finally, Section 5 summarizes the main findings and provides some policy implications.

\section{Theoretical Underpinnings}

The connection between financial development and economic growth has been a subject of considerable interest in the development of economic and finance literature in recent years. In this framework, financial development is considered to be the principal input for economic growth. It is an important element to affect the rate of economic growth by altering productivity growth and the efficiency of capital. It also affects the accumulation of capital through its impacts on savings rate by altering the proportion of savings (Pagano 1993; Levine 1997). The theoretical support can be traced back to the work of Schumpeter (1911) where he argues that financial intermediaries sector alter the mobilizing of savings for successful projects by managing risk, monitoring managers, and then facilitating transactions which will essentially improve technological innovation and economic development. In their seminal works, McKinnon (1973) and Shaw (1973) assert that the financial liberalization will increase savings and capital accumulation, which is finally to be invested and therefore enhances growth.

Heretofore, the development theory of economic growth has been widely used as literature in the study of economic development, macroeconomics, and other related subjects. Some of these theories were introduced by Rostow (1960), Harrod (1939), Domar (1946), Lewis (1954), and Solow (1956). However, only few of these theories focus explicitly on the role of financial development in promoting economic growth. On one hand, Harrod (1939) and Domar(1946) opine that in order to increase a growth rate, new investments representing net ad- 
units, would provide an efficient allocation of resources, thereby leading other economic sectors in their growth processes. This view has received considerable supports from recent empirical studies (Greenwood and Jovanovic 1990; Thakor 1996, to name a few).

The second one is "the growth-led finance hypothesis" or "the demandfollowing view." This view was advanced by Robinson (1952), and it states that financial development follows economic growth, or where an enterprise leads finance follows. Accordingly, as the real side of the economy expands, its demand for certain financial instruments, arrangements, and markets increases, leading to the growth of these services. Empirical supports for this second view can be found, for instances, in the studies of Friedman and Schwartz (1963) and Demetrides and Hussein (1996).

The third view is the "the feedback hypothesis" or "the bidirectional causality view." This view postulates that finance and economic developments are mutually causal and have bidirectional causality. In this hypothesis, it is asserted that a country with a well-developed financial system could promote high economic expansion through technological changes, products and services innovation (Schumpeter 1911). This will, in turn, create a high demand for the financial arrangements and services (Levine 1997). As the banking institutions effectively response to this demand, these changes will stimulate higher economic achievements. Both financial and economic developments therefore are positively interdependent, and their relationship could lead to bidirectional causality (Choong et al. 2003). Empirical supports for this view can also be found, for examples, in the works of Greenwood and Smith (1997) and Luintel and Khan (1999).

Eventually, the fourth view is "the independent hypothesis." This view was originally put forward by Lucas (1988), arguing that financial and economic development growth are not causally related, or in the words of Lucas (1988), "economics badly overstresses the role of financial factors in economic growth." Meanwhile, Chandavarkar (1992) notes that "none of the pioneers of the development economics....even list finance as a factor of development."

From the aforementioned exposition of different streams of thoughts on the relationship between financial and economic developments, it is obvious that the literature on this issue is mixed and inconclusive. Accordingly, it is appropriate and timely to empirically re-examine the finance-growth nexus in the largest Moslem population country, Indonesia. Does the finance-growth nexus in Indonesia support the first view (the finance-led growth hypothesis or the supply-leading view), the second view (the growth-led finance hypothesis or the demand-following view), the third view (the feedback hypothesis or the bidirectional causality view), or the last view (the independent hypothesis)? The extent to which 
provides more motivation for the study to adopt this model.

The ARDL model used in this study can be written as follows:

$$
\begin{aligned}
G D P_{t}= & \alpha_{0}+\alpha_{1} F D_{\mathrm{t}}+\alpha_{2} S I_{t}+ \\
& \alpha_{3} I N F_{t}+e_{t} \ldots \ldots \ldots \ldots \ldots \ldots \ldots
\end{aligned}
$$

where, $\mathrm{GDP}_{\mathrm{t}}=$ real output at time $t$,

$\mathrm{FD}_{\mathrm{t}}=\mathrm{a}$ measure of financial depth,

$S I_{t}=$ the share of investment,

$\mathrm{INF}_{\mathrm{t}}=$ inflation, and

$e_{\mathrm{t}} \quad=$ an error term.

The error correction version of ARDL framework pertaining to the variables in the Equation (1) can be reproduced as follows:

$$
\begin{aligned}
\Delta \mathrm{GDP}_{\mathrm{t}}= & \delta_{0}+\sum_{\mathrm{i}=1}^{\mathrm{p}} \varepsilon_{\mathrm{i}} \Delta \mathrm{GDP}_{\mathrm{t}-\mathrm{i}}+ \\
& \sum_{\mathrm{i}=0}^{\mathrm{p}} \phi_{\mathrm{i}} \Delta \mathrm{FD}_{\mathrm{t}-\mathrm{i}}+\sum_{\mathrm{i}=0}^{\mathrm{p}} \varphi_{\mathrm{i}} \Delta \mathrm{SI}_{\mathrm{t}-\mathrm{i}}+ \\
& \sum \gamma_{\mathrm{i}} \Delta \mathrm{INF}_{\mathrm{t}-\mathrm{i}}+\lambda_{1} \mathrm{GDP}_{\mathrm{t}-1}+ \\
& \lambda_{2} \mathrm{FD}_{\mathrm{t}-1}+\lambda_{3} \mathrm{SI}_{\mathrm{t}-1}+ \\
& \lambda_{4} \mathrm{INF}_{\mathrm{t}-1}+\mathrm{u}_{1 \mathrm{t}} \ldots \ldots \ldots \ldots . . .(2)
\end{aligned}
$$

The terms with the summation signs in the Equation (2) represent the error correction dynamic while the second part (termed with $\lambda \mathrm{s}$ ) corresponds to the long-run relationship. The null of no cointegration in the long-run relationship, defined with $H_{0}: \lambda_{1}=\lambda_{2}=$ $\lambda_{3}=\lambda_{4}=0$, is tested against the alter- native of $H_{0}: \lambda_{1} \neq \lambda_{2} \neq \lambda_{3} \neq \lambda_{4} \neq 0$ by the means of familiar $F$-test. However, the asymptotic distribution of this $F$-statistic is nonstandard irrespective of whether the variables are $I(0)$ or $I(1)$. For a small sample size ranging from 30 to 80 observations, Narayan (2004) has tabulated two sets of appropriate critical values. One set assumes that all variables are $I(1)$ and the other assumes that they are all $I(0)$. This provides a bound covering all possible classifications of the variables into $I(1)$ and $I(0)$ or even fractionally integrated. If the F-statistic exceeds the upper bound level, the null is rejected, which indicates the existence of cointegration. On the other hand, if the F-statistic falls below the bound level, the null cannot be rejected, which supports no cointegration. If, however, it falls within the band, the result is inconclusive.

Finally, in order to determine the optimal lag-length incorporated into the model and to select the ARDL model to be estimated, the study employs the Akaike Information Criteria (AIC). Since our study utilizes quarterly data with only 36 observations, the possible optimal lag-length to be considered is only 4 .

\section{Vector Error Correction Model (VECM) Framework}

To examine the multivariate causality relationship among the variables, the study employs the vector error correction model (VECM) framework. The VECM regresses the changes in 
Majid-Re-Examining The Finance Growth Nexus

strength of the causality among the variables beyond the sample period. Variance decompositions (VDCs) therefore allow us to examine the outof sample causality among the variables in the VAR system. It measures the percentage of the forecast error of variable that is explained by another variable. Precisely, it indicates the relative impact that one variable has on another variable. At the same time, it provides information on how a variable of interest responds to shocks or innovations in other variables. The VAR model is a system of reduced form dynamic linear equations in which each variable is expressed as a function of a serially uncorrelated errors and an equal number of lags of all variables in the system (Abdullah 1998; Enders 1995). This VAR model assumes that the contemporaneous correlations of errors across equations are nonzero, and therefore there are no contemporaneous explanatory variables in the model. The error terms (also referred to as innovations) can provide a potential source of new information on the movements in a variable during current period. In order to interpret the economic implications from the VAR model, Sim's (1980) innovation accounting procedure is employed. This procedure involves the decomposition of forecast error variance of each variable into components attributable to its own innovations and to shocks of other variables in the system.
The above procedures of VDCs together with the IRFs analysis (also renowned as innovation accounting in the literature) allow us to examine the relationships among the variables. If the correlations among the various innovations are large, the identification problem is likely to be important. The alternatives ordering should yield similar impulse responses and variance decompositions.

\section{Empirical Results}

Before estimating the long-run relationship between financial development and economic growth in Indonesia, we have to decide about the lag-

Table 1. F-statistics for Testing the Existence of a Long-run Relationship

\begin{tabular}{ccc}
\hline Lag-Length & & F-Statistics \\
\cline { 1 - 1 } 1 & & 1.04320 \\
2 & & $4.5543 * *$ \\
3 & & $8.4077 * * *$ \\
4 & & $6.3412 * * *$ \\
\cline { 1 - 2 } & &
\end{tabular}

Note: The relevant critical value bounds are taken from Case II with a restricted intercept and no trend and number of regressors $=3$ (Narayan, 2004). They are $4.480-5.700$ at the $99 \%$ significance level, $3.170-4.160$ at the $95 \%$ significance level and $2.618-3.502$ at the $90 \%$ significance level. $* *$, and $* * *$ denotes that F-Statistics falls above the $95 \%$, and $99 \%$ upper bound, respectively. 
mote economic development. ${ }^{4}$ Many previous empirical studies document that for countries with low inflation rate (below 10 percent annually), their economic growth will be accelerated (Bekaert et al. 2005; Gylfason et al. 2001; and Hung 2003), while high inflation (about 10 - 20 percent annually) could detriment the long-run economic growth (Gylfason et al. 2001; and Andrés et al. 2004). Our findings are in line with the later studies by Gylfason et al. (2001); Andrés et al. (2004) and Christopoulos and Tsionas (2004). In their study, Christopoulos and Tsionas (2004) find that during the period from 1997 to 2000 , a higher rate of inflation in Peru has spoilt the economic growth of the country. In promoting the growth of economy in Indonesia, it is very important for the government to maintain price stability by reducing the rate of inflation below two digits. A significant increase in the prices of petroleum and cooking oil in the early 2005 and mid-2006 respectively has hindered the growth of Indonesian economy, and it has also become one of the hindrances to the government to totally recover its economy.

Table 2: Multivariate 'VECM' Causality

\begin{tabular}{|c|c|c|c|c|c|}
\hline \multirow{2}{*}{$\begin{array}{l}\text { Dependent } \\
\text { Variables }\end{array}$} & \multicolumn{5}{|c|}{ Independent Variables } \\
\hline & $\Delta$ GDP & $\Delta \mathbf{F D}$ & $\Delta \mathbf{S I}$ & $\Delta \mathbf{I N F}$ & $\mathbf{E C T}_{\mathrm{t}-1}$ \\
\hline$\Delta$ GDP & - & $\begin{array}{c}1.3438 \\
{[0.2588]}\end{array}$ & $\begin{array}{l}2.6607 * \\
{[0.0923]}\end{array}$ & $\begin{array}{c}2.0512 \\
{[0.1360]}\end{array}$ & $\begin{array}{c}-1.4307^{* * *} \\
(-3.5972)\end{array}$ \\
\hline$\Delta$ FD & $\begin{array}{c}0.5405 \\
{[0.6596]}\end{array}$ & - & $\begin{array}{c}2.1997 \\
{[0.1346]}\end{array}$ & $\begin{array}{c}1.3082 \\
{[0.2968]}\end{array}$ & $\begin{array}{l}-0.1975^{*} \\
(-2.0432)\end{array}$ \\
\hline$\Delta \mathbf{S I}$ & $\begin{array}{c}4.7974 * * * \\
{[0.0102]}\end{array}$ & $\begin{array}{l}3.6600^{*} \\
{[0.0688]}\end{array}$ & - & $\begin{array}{c}1.2395 \\
{[0.3193]}\end{array}$ & $\begin{array}{c}0.0385 \\
(1.2656)\end{array}$ \\
\hline$\Delta \mathrm{INF}$ & $\begin{array}{c}1.6465 \\
{[0.2075]}\end{array}$ & $\begin{array}{c}0.1805 \\
{[0.6751]}\end{array}$ & $\begin{array}{c}0.6319 \\
{[0.5410]}\end{array}$ & - & $\begin{array}{c}-0.5203 * * \\
(-2.7004)\end{array}$ \\
\hline
\end{tabular}

Note: $* * * * *$ and $*$ represent significance at the $1 \%, 5 \%$ and $10 \%$ levels, respectively. $\mathrm{ECT}_{\mathrm{t}-1}$ is derived by normalizing the cointegrating vectors on the GDP as proxy for economic growth, producing residual $r$. By imposing restriction on the coefficients of each variable and conducting Wald test, we obtain $F$-statistics for each coefficient in all equations. Figures in the parentheses and squared parentheses represent $t$-statistics and probabilities for $F$-statistics, respectively.

${ }^{4}$ See, for example, the IMF report for the year 2005. The average rate of inflation of Indonesia was $10.45 \%$, while the rest of ASEAN countries had rates of inflation of between 0.5 and $9.4 \%$, i.e., Brunei Darussalam (1.22\%), Malaysia (2.96\%), Cambodia (5.56\%), Laos PDR (7.17\%), Myanmar (9.37\%), Philippines (7.64\%), Singapore (0.47\%), Thailand (4.54\%), and Vietnam $(8.25 \%)$. 
economic shocks may exacerbate macroeconomic instability and reduce the long-term growth. Thirdly, stock market development is likely to undermine the existing group-banking system in Indonesia which, despite their many difficulties, has not been without merit in Indonesia as well as in other highly successful East Asian economies.

To further explore the dynamic interaction between financial development and economic growth, the study proceeds to test the variance decompositions (VDCs) and impulse-response functions (IRFs). The results of VDCs that are reported in Table 3 provide detailed information on the relative strength of the financial depth, share of investment, and inflation in explaining the changes in the economic growth.
From the VDCs and IRFs results, we are also able to capture the relative importance of various shocks and their influences on the economic growth. The VDCs and IRFs are simulated by orthogonalizing the innovations in the vector autoregression(VAR) equations using the so-called Cholesky decomposition suggested by Sim (1980), with the ordering of the variables: GDP, FD, SI, INF. ${ }^{5}$ Based on VDCs results for the horizon of $1-12$ quarters as reported in Table 3, we find that the variations in the economic growth respond more to shocks in the price stability (inflation), and account for about $0-6.5$ percent of economic growth forecast error varianceafter three years. Meanwhile, the variations in the economic growth responding to shocks in the share of investment and financial

Table 3. Variance Decompositions

\begin{tabular}{|c|c|c|c|c|}
\hline \multirow{2}{*}{$\begin{array}{c}\text { Horizon } \\
\text { (Quarterly) }\end{array}$} & \multicolumn{3}{|c|}{ Explained by shocks in: } & \multirow[b]{2}{*}{ INF } \\
\hline & GDP & FD & SI & \\
\hline 1 & 100 & 0.00 & 0.00 & 0.00 \\
\hline 2 & 95.39 & 0.10 & 4.18 & 0.33 \\
\hline 4 & 89.07 & 0.78 & 4.96 & 5.19 \\
\hline 6 & 88.11 & 0.95 & 5.09 & 5.85 \\
\hline 8 & 87.46 & 1.12 & 5.02 & 6.39 \\
\hline 10 & 87.26 & 1.17 & 5.10 & 6.47 \\
\hline 12 & 87.19 & 1.20 & 5.06 & 6.55 \\
\hline
\end{tabular}

\footnotetext{
${ }^{5}$ We also have tried to use different orderings of the variables such as GDP, FD, INF, SI; GDP, INF, SI, FD; and GDP, INF, FD, SI, and to employ the generalized impulses which do not depend on the VAR ordering, as described by Pesaran and Shin (1998). However, their results are very much similar.
} 
Majid-Re-Examining The Finance Growth Nexus

\section{Continued from Figure 1}

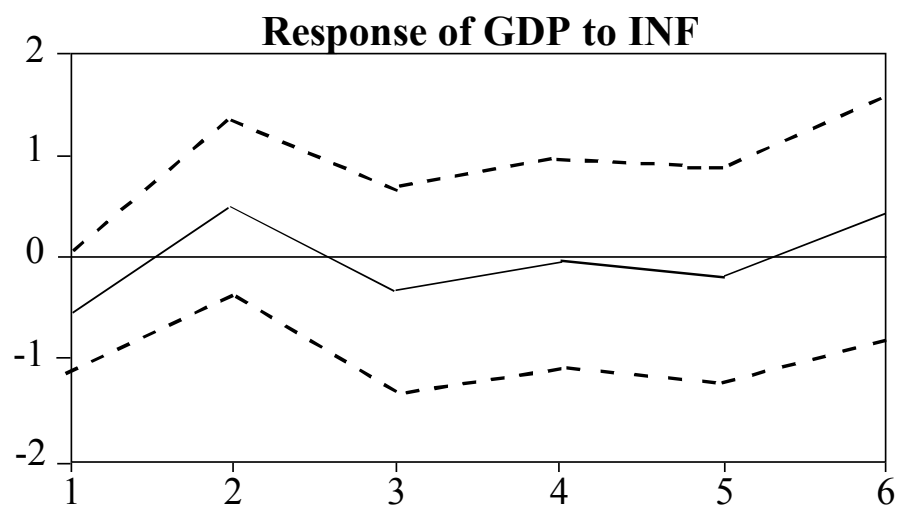

Figure 2. CUSUM and CUSUMSQ Plots

Plot of Cumulative Sum of Recursive Residuals

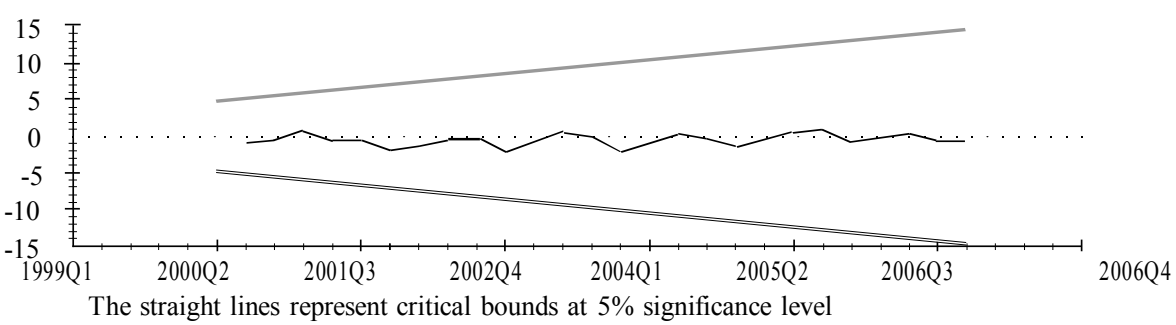

Plot of Cumulative Sum of Squares of Recursive Residuals

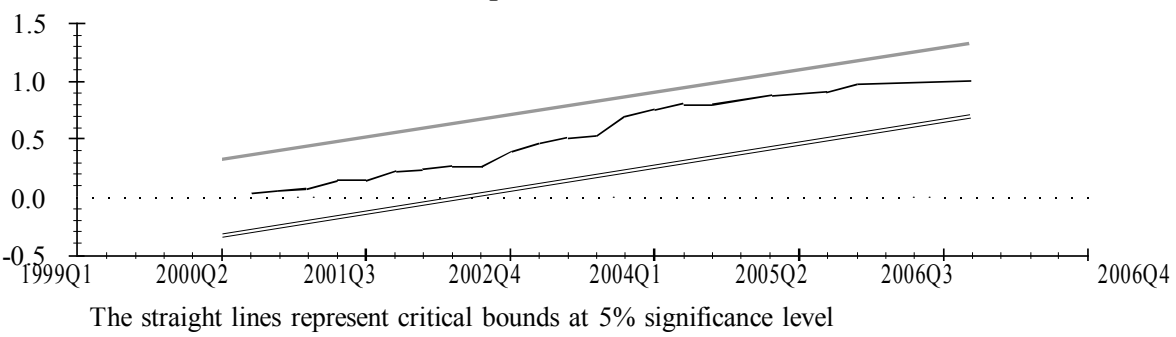

To complement our analysis on the VDCs, we further generate the IRFs, as described above. As reported in Figure 1, the overall results seem to be very much consistent with our earlier findings. Economic growth seems to have an immediate negative response to shocks in the price stability and share of investment, while no significant effect is found between the shocks in the financial development to the innovations in the economic growth. This further implies that any policies pertaining to the price stability and 
variations in the economic growth responding to shocks in the share of investment and financial development only account for about $0-5$ percent. Economic growth seems to have an immediate negative response to shocks in the price stability, while no significant effect is found between the shocks in the financial development and the innovations in the economic growth. The variations in the economic growth are, however, much depending on its own innovations.

The most important implication of our findings is a policy recommendation: if policy makers want to promote growth, then attention should be focused on maintaining the lower rate of inflation in the long run. However, any efforts put forward by the Indonesian government to promote the economic growth by further enhancing, deregulating, and restructuring the financial sector (banking and stock market) are found to be insignificant endeavours in promoting the growth of economy in Indonesia. As for the dynamic causalities among the variables, the study finds the bidirectional causation between economic growth and investment, while the unidirectional causation is only found running from financial depth to investment. On the other hand, to promote economic growth in the short run, the conducive investment environment should be improved by enhancing the modern the financial institutions, both in banking sector and in stock market.

Finally, this study has re-examined the finance-growth nexus financial turmoil in Indonesia during the post-1997 period. Hence, to enrich the findings, more robust analyses are needed, e.g., a comparative analysis between the pre- and post-1997 financial turmoil periods, thereby providing a comprehensive policy recommendation. Additionally, the enrichment of the findings could also be done by including more countries into the analysis, such as by examining all ASEAN countries. A comparative study between the ASEAN economies and developed markets would also provide additional insights into the existing empirical evidence.

\section{References}

Abdullah, D. A. 1998. Money growth variability and stock returns: An innovations accounting analysis. International Economic Journal 12 (4): 89-104.

Al-Yousif, Y. K. 2002. Financial development and economic growth: Another look at the evidence from developing countries. Review of Financial Economics 11: 131-150.

Andrés, J., I. Hernando, and J. D. Lo'pez-Salido. 2004. The role of the financial system in the growth-inflation link: The OECD experience. European Journal of Political Economy 20: 941-961.

Arestis, P., and P. Demetriades. 1997. Financial development and economic growth: Assessing the evidence. The Economic Journal 107: 783-799. 


\section{Majid-Re-Examining The Finance Growth Nexus}

Heinesen, E. 1995. A macroeconomic rationing model estimated by cointegration techniques and generalized method of moments. Economic Modelling 12 (2): $97-$ 110.

Hung, F. S. 2003. Inflation, financial development, and economic growth. International Review of Economics and Finance 12: 45-67.

International Monetary Fund. 2006. International Financial Statistic Online. www.imfstatistics.org.

Kasa, K. 1992. Common stochastic trends in international stock markets. Journal of Monetary Economics 29: 95-124.

Khan, S.M., and A. S. Senhaji. 2000. Financial and economic growth: An overview. IMF Working Paper. Washington: International Monetary Fund.

King, R.G., and R. Levine. 1993. Finance and growth: Schumpeter might be right. The Quarterly Journal of Economics: 717-737.

Laurenceson, J and J. C. H. Chai. 2003. Financial Reform and Economic Development in China. Cheltenham, UK: Edward Elgar.

Levine, R. 1997. Financial development and economic growth: Views and agenda. Journal of Economic Literature 35 (2): 688-726.

Lewis, W. A. 1954. Economic development with unlimited supplies of labour. The Manchester School 22: 139-191.

Lucas, R.E. 1988. On the mechanics of economic development. Journal of Monetary Economics 22 (1): 3-42.

Luintel, B.K., and M. Khan. 1999. A quantitative re-assessment of the finance-growth nexus: evidence from multivariate VAR. Journal of Development Economics 60: 381-405.

McKinnon, R. I. 1973. Money and Capital in Economic Development. Washington, DC: The Brooking Institution.

Mussa, M. 2006. Global economic prospects 2006/2007: Continued solid growth in 2006, rising risks for inflation, financial markets, and growth for 2007. Paper. Presented at the ninth semiannual meeting on Global Economic Prospects, Washington, DC, April 11.

Narayan, P. K. 2004. Reformulating critical values for the bounds f-statistics approach to cointegration: An application to the tourism demand model for Fiji. Discussion Paper No. 02/04. Department of Economics, Monash University. Australia.

Pagano, M. 1993. Financial markets and growth: An overview. European Economic Review 37: 613-622.

Pesaran, M. H., Y. Shin, and R. J. Smith. 1996. Testing for the existence of a long-run relationship. DAE Working Paper No. 9622. Department of Applied Economics, University of Cambridge.

Pesaran, M. H., and Y. Shin. 1998. Generelazied impulse response analysis in linear multivariate models. Economic Letters 58: 17-29. 